\title{
Mapping The Location Kuliah Kerja Nyata (KKN) State University Students Field in District Province North Sumatra
}

\author{
Charles Fransiscus Ambarita ${ }^{1 *}$, Jamalum Purba $^{2}$, M.Irfan ${ }^{3}$, Nono Hardinoto ${ }^{4}$ \\ 1,2,3,4 Universitas Negeri Medan, Medan, Indonesia \\ *charles.ambarita@yahoo.com
}

\begin{abstract}
Kuliah Kerja Nyata $(\mathrm{KKN})$ as a form of community service performed by college students through partnerships with provincial and local governments as one embodiment of the tri dharma college. KKN is a compulsory subject for students since the implementation of the curriculum at the University of Medan KKNI for students Strata 1 (S1) and the Education Program Non Education Program with weights 3 credits. Mapping the location of the exercise of this corruption has never been done before in the State University of Medan. Optimization efforts should be made to map the location of KKN. KKN is preparation for the 2020 school year. The research objective is to map the location of Kuliah Kerja Nyata (KKN) State University of Medan student. Outcomes research is the Standard Operational Procedure (SOP) Implementation of Kuliah Kerja Nyata (KKN) Students of State University of Medan, the publication of the proceedings of an international seminar, expected to be a policy of determining the location of State University of Medan student service learning and institutional quality improvement. This research is a descriptive research. The population in this study is all districts in North Sumatra province, amounting to 25 districts. Samples were taken from five districts of Deli Serdang, Langkat district, Serdang Berdagai, Karo and Samosir regency. The sampling technique used purposive sampling technique. The result of this research is to produce a draft Operational Standard Procedure (SOP) Implementation of Field Work Experience Student University of Medan. Instruments used in mapping the location of $\mathrm{KKN}$ will be used otherwise valid by the validator.
\end{abstract}

Keywords: Kuliah Kerja Nyata (KKN), Mapping, District.

\section{Introduction}

Tri dharma college is the duty of universities to provide education, research, and community service. In this respect, dedication to the community in question is the academic community activities that utilize science and technology to promote the welfare of society and intellectual life of the nation.

Law of the Republic of Indonesia Number 12 of 2012 on Higher Education in article 4 stating that higher education serves the academic community to develop an innovative, responsive, creative, skilled, competitive, and cooperative through the implementation of three dharma [1]. Furthermore, Article 5 states that the Higher Education aims to produce science and technology through research that observe and apply the value of the humanities in order to benefit the nation's progress, the progress of civilization, the welfare of mankind and the 
realization of community service-based reasoning and research works that are beneficial in promoting the general welfare and educating the nation.

Dedication to the community is an activity in the academic community and cultivate the practice of science and technology to promote the general welfare and educating the nation. Community service carried out in various forms of activities in accordance with the academic culture, expertise, and / or the autonomy of science academicians and social and cultural conditions. The results of community service is used as the process of the development of science and technology, the enrichment of learning resources, and / or for learning and maturation of the academic community [2].

Candy Ristekdikti Number 96 Year 2016 on the Statute of the University of Medan states that Unimed implement community service activities in order to utilize, utilization, development of science and technology, and other good practices. Community service carried out by the faculty and / or students and educators can engage.

Community service activities undertaken to provide contribution to regional development, innovation and transfer of technology, solutions to social issues, poverty alleviation and community empowerment

Kuliah Kerja Nyata $(\mathrm{KKN})$ as a form of community service performed by college students through partnerships with provincial and local governments as one embodiment of the tri dharma college. KKN is a lecture held directly in the middle of the community as the application of knowledge, skills and attitudes of students obtained on campus[3].

$\mathrm{KKN}$ as a learning process students through various activities directly in the middle of society, and actively and creatively involved as part of the community. Student involvement in corruption not only provide an opportunity for students to learn from the community, also have a positive impact on the optimal development potential of the village so as to give a new color in the society as a positive development that could ultimately improve the quality of people's lives.

One of the activities in the preparation phase is the implementation of service learning mapping and site characterization surveys of corruption. Survey mapping and location characteristics of corruption is an important thing to do as the initial stage of implementation of corruption.

This phase is conducted to obtain information about (1) the geographic description includes the distance to the district, the distance to the county, access to transport and communication access; (2) the potential for the village; (3) business unit village; (4) the characteristics of the village; (5) village program and (6) the number and level of school.

The results of this survey are used as a reference for the variation in the placement science students participating in service learning. Survey mapping and characterizing the location of corruption carried out in the district of North Sumatra province.

\section{Development Master Plan Unimed}

Based On Development Master Plan (RIP) Unimed Year 2011-2025, milestones achievements (milestones) of the goals stated in the Unimed target is further elaborated in the form of a Strategic Plan (Plan) five years. This means that the long-term trajectory of development Unimed 2011-2025 give emphasis to the 3 (three) profile through three stages of strategic plan goals, namely (1) the strengthening of services; (2) national competitiveness; and (3) regional competitiveness [4].

Unimed Development Year 2016-2020 in terms of national competitiveness that Unimed as a center of educational innovations that support the planning, execution, control, quality assurance and product familiarization national level research-based education. This is part of 
the implementation to realize the vision of Unimed, namely "Being a University of Excellence In Education, Engineering Industry and Culture".

Superior (excellence) has a meaning that is worth competitiveness or competitiveness. Unimed as a superior university is a form of existence that is more similar among universities in Indonesia in 2025. The Unimed Excellence is built based on projections, predictions and estimates on the achievements of the current actual condition.

Unimed excellence indicators at the national level in 2025, particularly the field of education is:

a) Become a referral institution in developing a learning system educators;

b) A reference in the development of curriculum-based character building and development;

c) Being the center of the assessment and development of characters (character building) and its internalization in education, management and leadership; and

d) Being a pioneer in the development of quality culture, including quality of service, education and learning, graduates and publications.

To meet the educational indicators, Unimed continue to review and develop the quality of learning by using a variety of approaches. The purpose of the assessment is to meet the needs of the graduates and their relevance to the actual conditions of Unimed existing resources. For that, there are 2 main focus of the study are (1) identifying competencies user needs research-based graduate or known as a profile of graduates, and (2) assessment of the optimization of the role and functions as well as the fulfillment of internal resources [5].

\section{Kuliah Kerja Nyata (KKN)}

KKN is a compulsory subject for students since the implementation of the curriculum at the University of Medan KKNI for students Strata 1 (S1) and the Education Program Non Education Program with weights 3 credits.

As subjects, the implementation of service learning gives students the opportunity to develop competencies through real learning in rural communities. A wide range of knowledge, skills and attitudes acquired in college can be implemented directly in the community such as the ability to think and reason analytically through the source of empirical and realistic, so as to design and implement programs to address the problems that exist in society, in collaboration with others both fellow student service learning and community participants, manage yourself, and train skills in working either as individuals or groups.

Thus, through the interaction of students and the public on the implementation of KKN obtained insight, experience, and skills of the basic formation of character formation of students.

Vision KKN University Of Medan is building the country of campus and student teaches of the village. KKN Mission State University of Medan is:

1) Educating students to apply and develop the competencies of knowledge, skills and attitudes in society; and

2) Empowering rural communities explore and exploit its potential to improve well-being.

Implementation of Kuliah Kerja Nyata (KKN) for students University of Medan aims to train and develop students' competencies in applying information theory and knowledge, skills and attitudes that have been obtained to the public with think and reason analytically through empirical and realistic sources, so as to design and implement programs to develop the potential of rural communities [3].

Kuliah Kerja Nyata (KKN) Unimed student involves four (4) components, namely the students, the community, the district and Unimed. 
The benefits of each component are as follows:

1) Building a multidisciplinary collaborations in thinking and working to solve a problem at the site of corruption;

2) Develop knowledge, skills and attitude in applying science and technology at the site of corruption; and

3) Train the ability to think in observation, study, formulating and solving the problem comprehensively based on empirical and realistic sources so that it can become an initiator and motivator for the empowering potential of rural communities KKN location.

The benefits society as a partner KKN implementation are as follows:

1) Acquire knowledge and skills to make observations, formulate, plan and implement rural development;

2) Acquire knowledge and experience in observing and empower rural potential to improve people's lives; and

3) Acquire the knowledge and skills of how to empower rural communities in order to form cadres to actively participate in sustainable development.

The benefits obtained by the KKN implementation partner districts Medan State University students are as follows:

1) Obtain information about the potential of the village through a comprehensive observation made by the student service learning; and

2) The results of the review, formulation and problem solving in a comprehensive plan based on empirical and realistic sources in which students can be used as initial information for rural development plan partners.

Unimed benefits gained in the implementation of service learning Medan State University students are as follows:

1) Pioneering and developing cooperation between the University of Medan with the District and the community can be as an initiator and motivator rural community empowerment; and

2) Got real information about phenomena that exist in society so to be used as reference in curriculum development University of Medan.

\section{North Sumatra Province}

North Sumatra is a province in Indonesia located in the northern part of the island Sumatra, This provincial capital is field, North Sumatra province consists of 25 districts and 8 cities; 325 districts and 5,456 villages / villages.2015 population census, the population of North Sumatra 13,937,797 inhabitants, with a population density of 191 people $/ \mathrm{km}^{2}$.

Based on the 2010 Census, the majority of North Sumatera vagabond, Inclusive of all sub-tribe of Batak. ThenJava, nias, Malay, Chinese, Minang, Aceh, row, India, and others.

In general, the language that is used extensively by the people of North Sumatra is Indonesian,

North Sumatra is rich in natural resources such as natural gas in the area Tandam, Binjai and petroleum Pangkalan Brandan, Langkat which has been explored since the days Dutch East Indies, Kuala Tanjung in Asahan there PT Inalum engaged in ore mining and smelting aluminum which is the only one in Southeast Asia,

The rivers that disgorge in the surrounding mountains Lake Toba is a natural resource that is sufficient potential to be a resource to be exploited hydroelectric plants. hydropower 
Asahan which is the largest hydropower plant in Sumatra are in Toba Samosir, The province is famous for its plantation area, up to now, the plantation economy of the province remains to be excellent. The plantations are managed by private companies and the state. SOE Plantation area is located in North Sumatra, including PT Perkebunan Nusantara II (PTPN II) PTPN III and PTPN IV.

\section{Research Method}

This research is a descriptive research. Descriptive research is research that is intended to gather information about the status of an existing symptoms, the symptoms according to what their circumstances at the time of research [6]. This study aimed to get a picture of the studied subject. Processing of the data is based on the percentage of analysis and trend analysis (trend) without linking the state of the population in which the data was taken. The population in this study are all districts in the province of North Sumatra as many as 25 districts and samples in this study were 5 districts purposive sampling.

The data in this study were obtained through questionnaires and documents [7]. Questionnaire used to collect information sourced respondents from government and villagers in the district of North Sumatra, while documentation is the whole thing can be obtained from the field, can be data or photographs.

This research data analysis techniques in accordance with the purpose of this study was to determine the results of the survey and student service learning site characterization State University of Medan in North Sumatra province, the research data that have been collected then analyzed by qualitative descriptive.

\section{Results and Discussion}

Kuliah Kerja Nyata (KKN) University of Medan is one of the compulsory subjects are coordinated by the Institute for Research and Community Services (LPPM) Unimed. CCN in Unimed aims to provide a learning experience to the students through the application of science, technology and art. CCN provides a positive contribution to the development of society and the state. $\mathrm{CCN}$ is held once a year.

\section{a. Problem analysis}

From the identification of the problem conducted by the Center of corruption, PPL, and Internship Unimed, the problems that occur are Unimed not yet have a location mapping as a student service learning. Constraints of the lack of such mapping Unimed difficult to place students attend learning programs.

To overcome these problems, an optimization effort is needed to map the location of the community service program so that the implementation of the community service program will not become an obstacle for University of Medan.

\section{b. Data Needs Analysis}

To perform the mapping required the input of the data that will be analyzed in order to provide information regarding the location of Kuliah Kerja Nyata (KKN) and can be used as a policy of determining the location of KKN. Data and information needs for mapping the 
location of the data service learning for students is a village or district as the location KKN. KKN will be a place for students. namely in the form of (1) an overview covering geographic distance from the village to the township, village distance to the county, access to transport and communication access, (2) the potential for the village; (3) business unit village; (4) the characteristics of the village; (5) village program; and (6) the amount and level of school.

\section{c. Instrument Validation Results}

Once the analysis stage of problem analysis and data needs, the next step of this research is the validation of the instruments mapping the Kuliah Kerja Nyata $(\mathrm{KKN})$. This validation is useful for determining and revising the need to be assessed in mapping the location of Kuliah Kerja Nyata (KKN)

Validator is an expert who is experienced in knowing the location of the villages in the province of North Sumatra. Validation of experts validate KKN location mapping instrument that will be used by the validator to validate the Standard Operational Procedures (SOP) Implementation of student service learning Unimed, But the discussion of these results only up to the validation of the instrument.

In the validation phase of instruments, there is some input from the respective experts and are summarized as follows:

Table 1. Revision Instruments Mapping Location KKN

\begin{tabular}{l} 
No. \\
(1) \\
\hline $1 \quad$ Validator 1 and 2 \\
Validation of the results is as follows: \\
a) Questions or statements on the location of the more refined instrument in order to \\
obtain sufficient information on the location of the village KKN \\
b) Coverage questions / statements designed instrument in question please expanded field \\
c) Arranged inside the instrument has been no question / statement education. These \\
learning programs need to know the state of education in each village. \\
d) Programs village excavated in the instrument is too narrow so that information about \\
the village program that has been implemented, ongoing and will be implemented has \\
not been unraveled.
\end{tabular}




\section{d. Results Mapping Each District}

Description of the mapping results in each district is as follows:

\section{a. Samosir}

Samosir picture as the location of Kuliah Kerja Nyata (KKN) University of Medan students based on data obtained in the field and after the analysis with statistical analysis, it can be seen in the following table:

Table 2. Results of mapping Samosir

\begin{tabular}{llll}
\hline NO & COMPONENT & $\begin{array}{l}\text { PERCENT } \\
\text { TASE }\end{array}$ & CRITERIA \\
\hline 1 & Geographical overview & $50 \%$ & Average \\
& & & Very high \\
2 & Potential Village & $87.5 \%$ & Average \\
3 & Business Unit Desa & $45 \%$ & High \\
4 & Village characteristics & $75 \%$ & High \\
5 & Village program & $75 \%$ & High \\
6 & Jejang And Number Of & $77.5 \%$ & \\
\hline & Schools & & High \\
\hline
\end{tabular}

More specifically readiness Samosir district as the location of University of Medan student service learning can be presented graphically in the following charts:

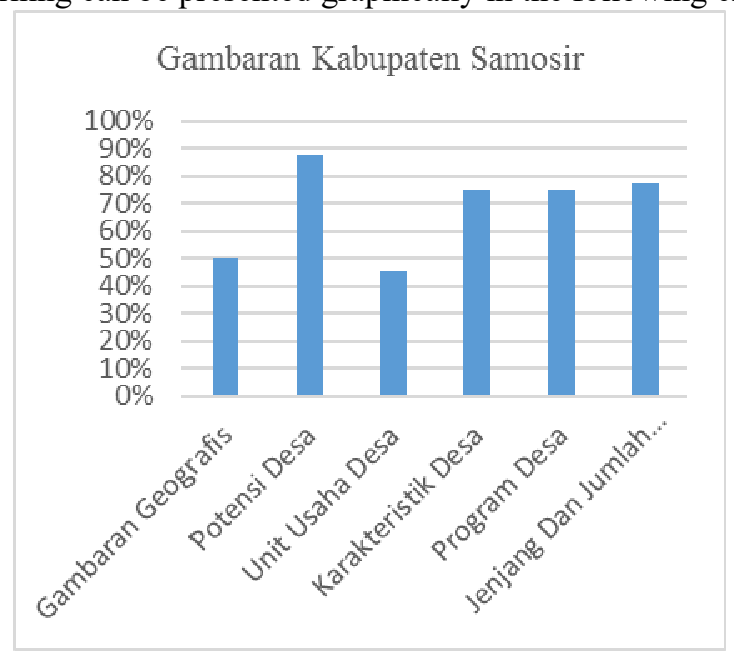

Fig 1. Overview Samosir 


\section{b. Langkat}

Langkat picture of the condition can be seen in the following table:

\begin{tabular}{clll}
\multicolumn{4}{c}{ Table 3. Mapping Langkat } \\
\hline NO & COMPONENT & PERCENTAGE & CRITERIA \\
\hline 1 & Geographical overview & $75 \%$ & High \\
& & $72.5 \%$ & High \\
2 & Potential Village & $50 \%$ & Average \\
3 & Business Unit Desa & $60 \%$ & Average \\
4 & Village characteristics & & High \\
5 & Village program & $75 \%$ & High \\
6 & $\begin{array}{l}\text { Jejang And Number } \\
\text { Schools }\end{array}$ & $80 \%$ & High \\
& Average & $\mathbf{6 8 . 7 5 \%}$ &
\end{tabular}

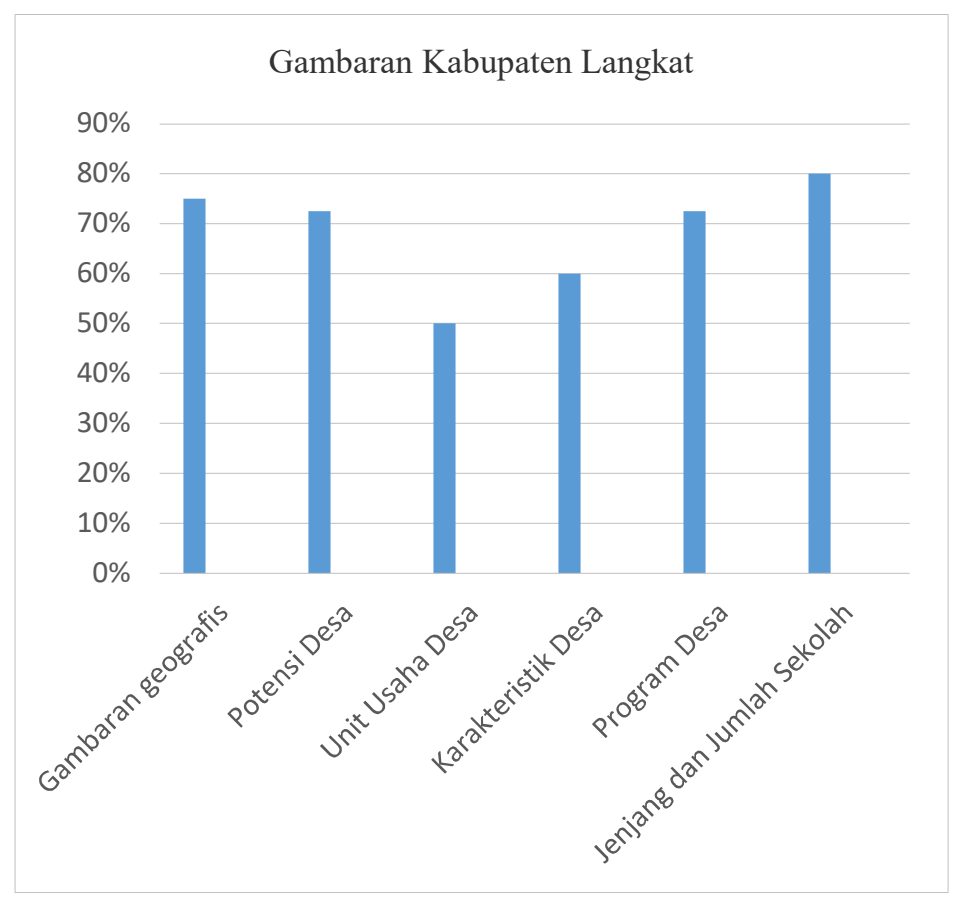

Fig 2. Overview Langkat 


\section{c. Karo}

Langkat picture of the condition can be seen in the following table:

Table 4. Results of Mapping Karo

\begin{tabular}{clll}
\multicolumn{4}{c}{ Table 4. Results of Mapping Karo } \\
\hline NO & \multicolumn{1}{c}{ COMPONENT } & \multicolumn{1}{c}{ PERCENTAGE } & CRITERIA \\
\hline 1 & Geographical overview & $45 \%$ & Average \\
2 & Potential Village & $82.5 \%$ & Very high \\
3 & Business Unit Desa & $60 \%$ & Average \\
& & & High \\
4 & Village characteristics & $72.5 \%$ & High \\
5 & Village program & $75 \%$ & Very high \\
6 & Jejang And Number Of & $82.5 \%$ & \\
& Schools & & High \\
& & $\mathbf{6 9 . 5 8 \%}$ & \\
\hline
\end{tabular}

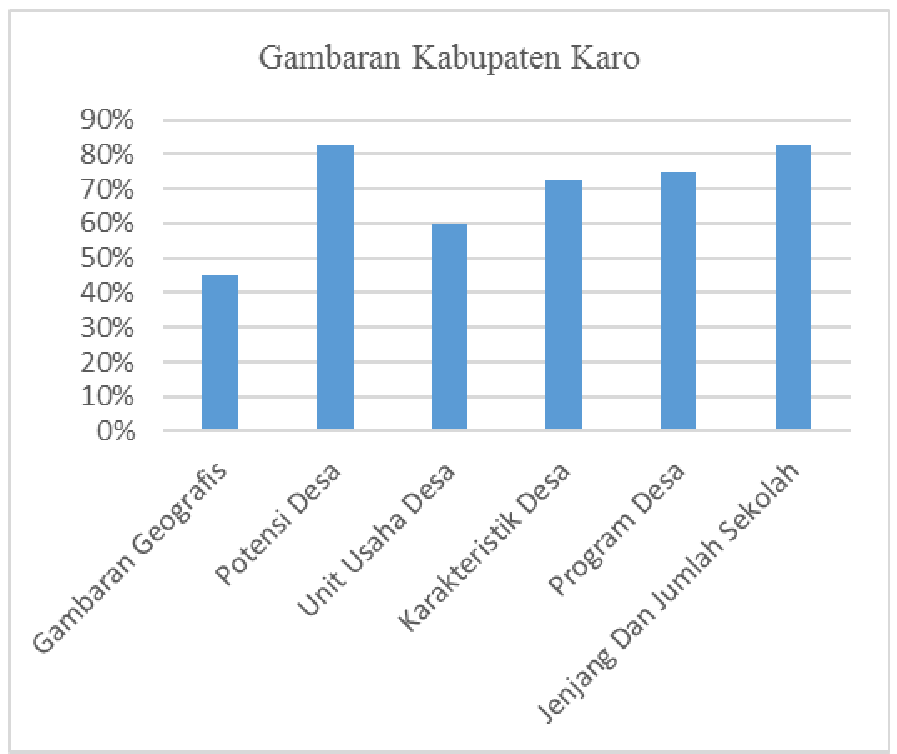

Fig 3. Results Mapping Karo 


\section{d. Serdang Berdagai}

Overview Serdang Berdagai conditions seen in the following table:

Table 5. Results of Mapping Serdang Berdagai

\begin{tabular}{clll}
\multicolumn{4}{c}{ Table 5. Results of Mapping Serdang Berdagai } \\
\hline NO & \multicolumn{1}{c}{ COMPONENT } & \multicolumn{1}{c}{ PERCENTAGE } & CRITERIA \\
& & & High \\
\hline 1 & Geographical overview & $75 \%$ & High \\
2 & Potential Village & $70 \%$ & Average \\
3 & Business Unit Desa & $57.5 \%$ & High \\
4 & Village characteristics & $67.5 \%$ & High \\
5 & Village program & $70 \%$ & High \\
6 & Jejang And Number Of & $75 \%$ & High \\
& Schools & &
\end{tabular}

Gambaran Kabupaten Serdang Berdagai

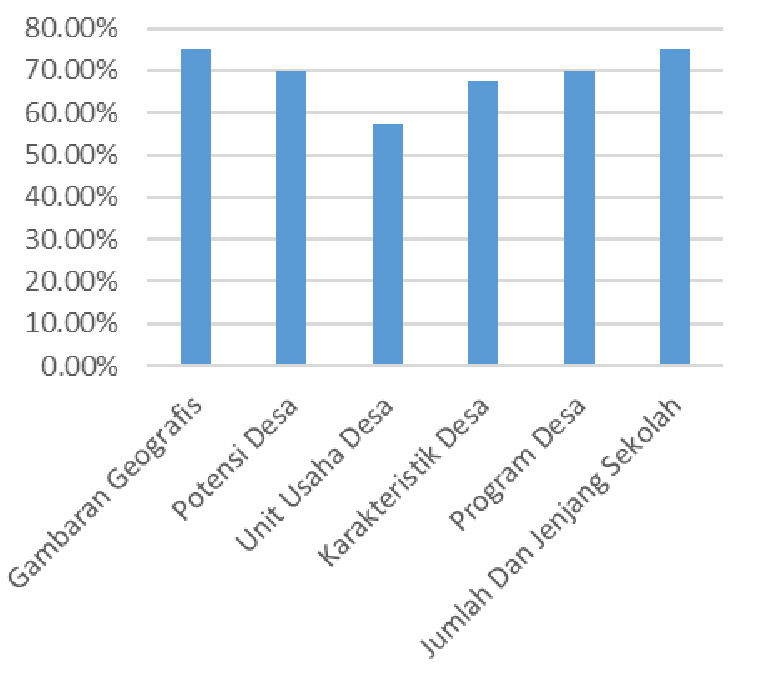

Fig 4. Overview Serdang Berdagai 


\section{e. Deli Serdang}

Deli Serdang picture of the condition can be seen in the following table:

Table 6. Outcome Mapping Deli Serdang

\begin{tabular}{llll}
\hline & \multicolumn{1}{c}{ COMPONENT } & \multicolumn{1}{c}{ PERCENTAGE } & \multicolumn{1}{c}{ CRITERIA } \\
\hline 1 & geographical overview & $77.5 \%$ & High \\
2 & potential Village & $67.5 \%$ & High \\
3 & Business Unit Desa & $65 \%$ & High \\
& & & High \\
4 & Village characteristics & $70 \%$ & High \\
5 & Village program & $65 \%$ & Very high \\
6 & Jejang And Number Of & $85 \%$ & \\
& Schools & & High \\
\hline
\end{tabular}

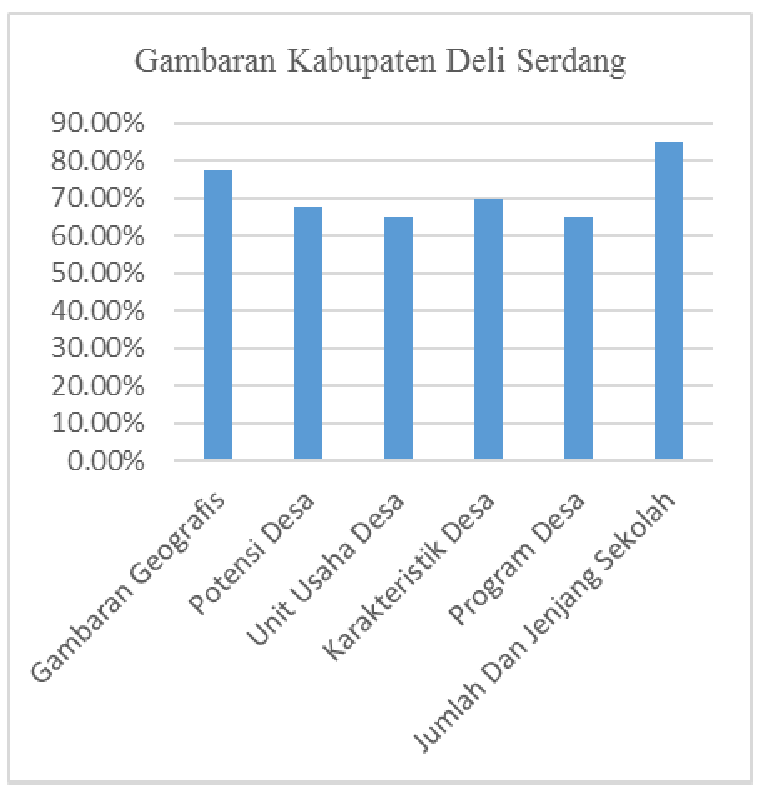

Fig 5. Overview of Deli Serdang

\section{Discussion}

According Nieveen in Subekti in $[4,8]$ the validity of a product can be attributed to two things: 1) whether the development is based on a strong theoretical rationale, and 2) 
whether there is internal consistency. In addition, the determination of validity is determined by experts (experts) or people who know about a product.

KKN location mapping instrument Unimed student has been revised by the validator and declared worthy instruments to obtain information on the mapping of districts in North Sumatra province.

Results of mapping each district has a high potential to be the location of Kuliah Kerja Nyata (KKN) University of Medan student.

\section{Conclusion}

From the research and discussion above, this research has resulted in several conclusions as follows:

1) KKN location mapping instrument was revised by the validator and worth as a tool to obtain information about the location of corruption in the district of North Sumatra Province

2) Mapping results Samosir earned an average of $68.3 \%$ with a high criteria, Langkat district earned an average of $68.75 \%$ with a high criteria, Karo earned an average of $69.58 \%$ with a high criteria, Serdang Berdagai obtain the mean average $69.1 \%$ with high criteria and Deli Serdang district earned an average of $71.66 \%$ with high criteria.

Based on the above conclusion, this study resulted in the following recommendations:

1) The study has recommended that Samosir regency, Langkat, Karo, Serdang Berdagai and Deli Serdang worthy KKN location University of Medan students.

2) The results could provide input for sample districts in North Sumatra province to be able to add information about the district.

\section{References}

[1] Regulation of the Minister of Education and Culture of the Republic of Indonesia Number 49/ 2014 On National Standards for Higher Education (2014).

[2] Law of the Republic of Indonesia Number 12. (2012).

[3] Institute for Community Services, Guidelines for Real work Lecture, KKN), Singaraja: Ganesha Education University, (2012)

[4] Permenristekdikti No. 96 Year 2016 Statute of the State University of Medan (2016).

[5] Technology and Higher Education, Guidelines for National Lecture real work, Jakarta: Directorate of Student Affairs, (2018)

[6] Ali, M., and M., Asrori, Educational Research Methodology and Applications, Jakarta: Earth Literacy. (2014)

[7] Nazir, M. Methods, Bagar, Ghalia Indonesia. (2014)

[8] Mulyadi; Ismail; Rakib, M. Revelation, Guidelines for Implementation of Real Work Lecture, Makassar Makassar State University LPM. (2015). 